\title{
Diagnostic Role of F-18 Fluorodeoxyglucose Positron-Emission Tomography/Computed Tomography in Restaging of Upper Urinary Tract Urothelial Carcinoma
}

\author{
Üst Üriner Sistem Transizyonel Hücreli Karsinomlarının Yeniden Evrelendirilmesinde F-18 \\ Florodeoksiglukoz Pozitron-Emisyon Tomografisi/Bilgisayarlı Tomografinin Tanısal Rolü
}

\author{
Hakan Öztürk \\ Medicalpark İmir Hospital, Clinic of Urology, İzmir, Turkiye
}

\section{What's known on the subject? and What does the study add?}

There are quite few data in the literature about re-staging of upper urinary tract urothelial carcinoma with positron-emission tomography/ computed tomography (PET/CT). We may see in the study that PET/CT detects local recurrence and distant metastasis with high specificity.

\begin{abstract}
Objective: To retrospectively evaluate contribution of F-18 fluorodeoxyglucose positron-emission tomography/computed tomography $\left({ }^{18} \mathrm{FDG}-\mathrm{PET} /\right.$ CT) to re-staging of upper urinary tract urothelial carcinoma (UTUC).

Materials and Methods: This study included a total of 17 patients (12 males and 5 females), who underwent nephroureterectomy due to UTUC and ${ }^{18}$ FDG-PET/CT between July 2007 and April 2015. The mean age of the patients was 64.3 \pm 9.96 years (range: 45-79). ${ }^{18} \mathrm{FDG}-\mathrm{PET} / \mathrm{CT}$ was performed for re-staging 6-24 months after nephroureterectomy (mean: 18 months). Nearly 1 hour after intravenous injection of 555 MBq of F-18 FDG, the patients underwent whole-body PET scanning from the skull base to the upper thighs after 6 hours of fasting, and nearly 1 hour after all body CT scanning performed in the craniocaudal direction. By using CT data for attenuation correction, FDG-PET images were reconstructed.

Results: ${ }^{18} \mathrm{FDG}-\mathrm{PET} / \mathrm{CT}$ scans proved negative findings in three patients $(17.7 \%)$ and positive findings in 14 patients (82.3\%). Suspicious recurrent or metastatic lesions were confirmed by histopathology or clinical follow-up. Sensitivity of ${ }^{18}$ FDG-PET/CT was $93 \%$ and the specificity was $75 \%$.

Conclusion: ${ }^{18} \mathrm{FDG}-\mathrm{PET} / \mathrm{CT}$ defines local recurrence and far metastases with high specificity in re-staging of operated UTUC. It is thought that the procedure could play an important role in decisions regarding radiotherapy or chemotherapy and post-operative follow-up after the operation and could affect the whole decision-making process.

Keywords: Upper urinary tract urothelial carcinoma, positron-emission tomography, positron-emission tomography/computed tomography, restaging

\section{Öz}

Amaç: Üst üriner sistem ürotelyal karsinomlarının (UTUC) yeniden evrelendirilmesinde F-18 florodeoksiglukoz pozitron-emisyon tomografisi/ bilgisayarlı tomografinin ( $\left.{ }^{18} \mathrm{FDG}-\mathrm{PET} / \mathrm{BT}\right)$ katkısını retrospektif olarak incelemektir.

Gereç ve Yöntem: Temmuz 2007 ile Nisan 2015 tarihleri arasında UTUC nedeniyle nefroüreterektomi yapılan ve yeniden evreleme amacıyla

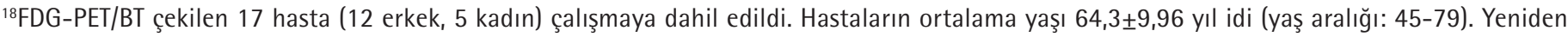
evreleme için ${ }^{18} \mathrm{FDG}-\mathrm{PET} / \mathrm{BT}$ çalışması nefroüreterektomi sonrası 6-24 ay sonra (ortalama 18 ay) yapıldı. Hastalar taramadan önce 6 saat boyunca aç bırakıldı ve kafa tabanından üst uyluk bölgesine kadar olan alanda F-18 FDG $555 \mathrm{MBq}$ intravenöz enjeksiyonundan yaklaşık 1 saat sonra tüm vücut PET taraması yapıldı. Tüm vücut BT taraması kraniokaudal yönünde yapıldı. FDG-PET imajları doğrulama için BT dataları kullanılarak rekonstrükte edildi.
\end{abstract}

Correspondence: Hakan Öztürk MD, Medicalpark İzmir Hospital, Clinic of Urology, İzmir, Turkiye

Phone: +90 5323030195 E-mail: drhakanozturk@yahoo.com.tr ORCID-ID: orcid.org/0000-0002-4962-7707

Received: 23.07.2017

Accepted: 07.08.2017

Cite this article as: Öztürk H. Diagnostic Role of F-18 Fluorodeoxyglucose Positron-Emission Tomography/Computed Tomography in Restaging of Upper Urinary Tract Urothelial Carcinoma. J Urol Surg 2017;4:122-128.

๑Copyright 2017 by the Association of Urological Surgery / Journal of Urological Surgery published by Galenos Publishing House. 
$\ddot{0 z}$

Bulgular: ${ }^{18} \mathrm{FDG}-\mathrm{PET} / \mathrm{BT}$ görüntüleme üç hastada $(\% 17,7)$ negatif, 14 hastada $(\% 82,3)$ pozitifti. Şüpheli tekrarlayan veya metastatik lezyonlar histopatolojik olarak ya da klinik izlem ile teyit edildi. ${ }^{18}$ FDG-PET/BT'nin duyarlılık ve özgüllüğü sırasıyla \%93 ve \%75 idi.

Sonuç: Opere UTUC'nin yeniden evrelemesinde ${ }^{18} \mathrm{FDG}$-PET/BT lokal nüks ve/veya uzak metastazları yüksek doğrulukta saptayabilmektedir. Operasyon sonrası takip ile radyoterapi ve kemoterapi kararının verilmesi ve tedavi sonrası takibin yapılmasında önemli bir rol oynayabileceği ve karar vermeyi etkileyebileceği düşünülmektedir.

Anahtar Kelimeler: Üst üriner sistem ürotelyal karsinoma, pozitron-emisyon tomografisi, pozitron-emisyon tomografisi/bilgisayarlı tomografi, yeniden evreleme

\section{Introduction}

Urothelial cancers are the fourth most common cancers after prostate or breast cancers, lung, and colorectal cancers (1). However, upper urinary tract urothelial carcinoma (UTUC) is an extremely rare cancer and accounts for $5-10 \%$ of all urothelial cancers (2). The estimated annual incidence of UTUC in Western countries is about one or two new cases per 100.000 inhabitants. The rate of concomitant bladder carcinoma ranges between $8 \%$ and $13 \%$ in patients diagnosed with UTUC. Of these patients, $30-51 \%$ develop recurrence in the bladder, and ipsilateral recurrence occurs in 2-6\% (3). An invasive cancer is present in $60 \%$ of patients at the diagnosis of UTUC. The disease makes a peak in patients aged $70-80$ years, and the ratio of male to female is $3: 1$. There have been familial/hereditary cases of UTUC linked to hereditary nonpolyposis colorectal carcinoma (1). Environmental carcinogens and smoking are the most important etiological factors. Furthermore, the polymorphism reducing the activity of sulfotransferase which triggers the development of UTUC is the only genetic etiological factor described in the literature (4). Histopathologically, these tumors are classified similar to bladder cancers as carcinoma in situ (CIS), lowgrade and high-grade. Multidetector computed tomography urography (MDCTU) is the gold standard method in the diagnosis of UTUC (5). UTUCs invading the muscle wall usually have a very poor prognosis. The 5-year cancer-specific survival is $<50 \%$ for pT2/pT3 and $<10 \%$ for pT4 (6). Gender and localization of the tumor are considered to be of no prognostic significance. Advanced age, presence of lymphovascular invasion, presence of necrosis, sessile growth pattern of the tumor, and presence of CIS may predict poor prognosis (1). Radical nephroureterectomy with excision of the bladder cuff is the gold standard treatment for UTUCs, regardless of the location of theatumor in the upper urinary tract (7). All patients should be followed up after radical nephroureterectomy for possible development of metachronous bladder tumor. Cisplatin-based chemotherapy regimens can be used in UTUCs. However, adjuvant chemotherapy achieves a recurrence-free rate of up to $50 \%$ but has minimum impact on survival (8). Adjuvant radiotherapy can achieve local disease control (9).
UTUC requires follow-up with cytology, cystoscopy, ureterorenoscopy, and MDCTU after surgery. However, diagnosis of distance metastases and local recurrence remain challenging in operated UTUC. Moreover, there is a need for a diagnostic test providing high sensitivity and specificity in determining residual disease and monitoring response to treatment after radiotherapy and chemotherapy. F-18 fluorodeoxyglucose positron-emission tomography/computed tomography $\left({ }^{18} \mathrm{FDG}-\mathrm{PET} / \mathrm{CT}\right)$ is the most important diagnostic instrument providing functional and anatomical images. The most important aim of this study was to define the role of ${ }^{18} \mathrm{FDG}-\mathrm{PET} / \mathrm{CT}$ in re-staging UTUC after surgery. The histological conclusions (where available) or the total clinical and radiological workup (MDCTU, magnetic resonance imaging) were used as a standard reference.

\section{Materials and Methods}

A total of 7938 patients were evaluated and $10553{ }^{18}$ FDG-PET/ CT scans were performed in the nuclear medicine department between July 2007 and April 2015. In this patients group, 17 [12 males (70.5\%) and 5 females (29.5\%)] were diagnosed with operated upper urinary tract carcinoma and underwent ${ }^{18} \mathrm{FDG}-\mathrm{PET} / \mathrm{CT}$ for re-staging of the tumor. ${ }^{18} \mathrm{FDG}-\mathrm{PET} / \mathrm{CT}$ study was performed after nephroureterectomy in all patients. PET/ CT was made once 6-24 months post-operatively. All patients were diagnosed with transitional cell carcinoma (TCC) based on histopathological and immunohistochemical evaluation. The mean age of the patients was $64.3 \pm 9.96$ years (range: $45-79$ ). According to the grading system of the European Association of Urology (EAU) for upper urinary tract TCC, two patients (11.7\%) had low-grade and 15 patients (88.3\%) had-high grade tumor. The patients were re-evaluated with ${ }^{18} \mathrm{FDG}-\mathrm{PET} / \mathrm{CT}$ for re-staging due to suspicion of disease recurrence besides other radiologic or clinical analyses done to perform routine follow-up. These patients were evaluated retrospectively, and pathological findings and ${ }^{18} \mathrm{FDG}-\mathrm{PET} / \mathrm{CT}$ data were recorded.

All procedures followed were in accordance with the ethical standards of the responsible committee on human experimentation and with the Helsinki Declaration of 1975, as revised in 2000. The study does not have approval of the ethical committee as it is retrospective but, informed consent 
was obtained from all patients for being included in the study. Additional information consent was obtained from all patients for which identifying information is included in this article.

\section{Imaging and Interpretation of Data}

F-18 fluorodeoxyglucose was synthesized using an in-house cyclotron (Siemens) and an automated synthesis system according to the authorized procedure. After five hours of fasting, blood glucose level of each patient was measured, and the patient was then intravenously injected with $370 \mathrm{MBq}$ of F-18 FDG. One hour after F-18 FDG injection, a CT scan without contrast agent was performed, covering the area from the vertex to the proximal thigh, and the images were used for attenuation correction and image fusion. This was followed by wholebody 3D PET acquisition with 8 bed positions of 3 minutes of emission scan time each using a dedicated PET/CT scanner (HIREZ Biograph 6, Siemens) which provides an in-plane spatial resolution of $4.8 \mathrm{~mm}$, an axial field view of $16.2 \mathrm{~cm}$. The PET data were reconstructed using a Gaussian filter with an orderedsubset expectation maximization algorithm (3 iterations, 8 subsets), re-oriented in transverse, coronal and sagittal planes, and assessed by comparing them with corresponding CT images.

PET scans were analyzed visually and semi-quantitatively using maximum standardized uptake value $\left(\mathrm{SUV}_{\max }\right)$ measurement. SUV was expressed in terms of body weight (SUVbw $-\mathrm{g} / \mathrm{mL}$ ). The parameters such as patient's weight $(\mathrm{kg})$, height $(\mathrm{cm})$, radioactivity during injection $(\mathrm{MBq})$, residual radioactivity $(\mathrm{MBq})$ after the injection, starting time of injection, and halflife of the radioisotope (taken as standard 109.8 minutes for 18-FDG) were calculated automatically by the software.

Two experienced nuclear medicine physicians reviewed blindly and independently the hybrid FDG PET/CT scans as positive or negative for a primary tumor site. Every focal tracer uptake that deviated from physiological distribution was considered in favour of disease spread. The background deviation and activity difference between the suspected lesion and the surrounding tissues were used to differentiate benign from malignant lesions. Therefore, SUV max $>2.5$ threshold was employed.

\section{Statistical Analysis}

All statistical data analyses were calculated using SPSS statistics software (version 16.0; SPSS, Inc., Chicago, Illinois, USA). All statistical data analyses were calculated using Fisher's exact test. $\mathrm{P}<0.05$ was considered to indicate a statistically significant difference.

\section{Results}

${ }^{18} \mathrm{FDG}-\mathrm{PET} / \mathrm{CT}$ scans presented negative findings in three patients $(17.7 \%)$ and positive findings in 14 patients (82.3\%). Four patients $(23 \%)$ had widespread metastases with high SUV involving at least two organs (lungs, bone, lymph nodes, etc.). Eleven patients (64.7\%) had lymph node metastasis (mean SUV $_{\max }: 5.8$, min: 3.6, max: 11.3), four patients (23\%) had bone metastasis (mean SUV $_{\max }: 8.8$, min: 5.4 , max: 14.8), and three patients (17.6\%) had liver metastasis. None of the patients had metachronous bladder carcinoma or disease recurrence in the contralateral upper urinary tract. PET scans were negative in all patients classified as low grade according to the EAU grading system, and patients with high-grade tumor showed positive findings on PET (Table 1). The results of ${ }^{18} \mathrm{FDG}-\mathrm{PET} / \mathrm{CT}$ scans according to histological grade are presented in Table 1. The rate of PET-positive studies is higher if the grade of the tumor is high. The mean SUV max $_{\text {mas }} 7.1$ (min: 3.6, max: 17) in patients with positive PET/CT findings. ${ }^{18} \mathrm{FDG}-\mathrm{PET} / \mathrm{CT}$ results correlated with histological subtype in possibility charts $(p<0.05)$. Suspicious recurrent or metastatic lesions were confirmed by histopathology or clinical follow-up. Sensitivity and specificity of ${ }^{18} \mathrm{FDG}-\mathrm{PET} / \mathrm{CT}$ were $93 \%$, 75\% respectively (Figures 1, 2, 3, and 4).

\section{Discussion}

UTUC is associated with extremely poor prognosis. Radical nephroureterectomy and bladder cuff excision is the gold standard treatment method for UTUCs regardless of the localization of the tumor in the upper urinary tract (7). Since local recurrence and metastatic disease substantially decline survival in patients with UTUC, establishing exact diagnosis and providing prompt treatment are of crucial importance. Restaging of the disease, minimizing false-positivities and falsenegativities, and more importantly, recognition of metastatic disease constitute the most important and realistic part of determining the treatment strategy. In the light of current literature data, current follow-up programs routinely used in clinical follow-up of operated UTUC in general focus on the search for the presence of metachronous bladder carcinoma and/or upper urinary tract tumor. ${ }^{18} \mathrm{FDG}-\mathrm{PET} / \mathrm{CT}$ is the most significant diagnostic instrument that provides functional and anatomical images.

Establishing the diagnosis of primary UTUC using ${ }^{18}$ FDG-PET

Table 1. Positron-emission tomography/computed tomography results according to histological findings and grade of the primary tumor

\begin{tabular}{lll}
\hline TCCa histological grade & $\begin{array}{l}\text { PET/CT positive } \\
\mathbf{n}_{\mathbf{1}}(\mathbf{\%})\end{array}$ & $\begin{array}{l}\mathrm{PET} / \mathrm{CT} \text { negative } \\
\mathbf{n}, \mathbf{( \% )}\end{array}$ \\
\hline Low grade & 0 & $2(100 \%)$ \\
High grade & $15(100 \%)$ & 0 \\
\hline $\begin{array}{l}\text { TCC: Transitional cell carcinoma, PET/CT: Positron-emission tomography/computed } \\
\text { tomography }\end{array}$ \\
\hline
\end{tabular}




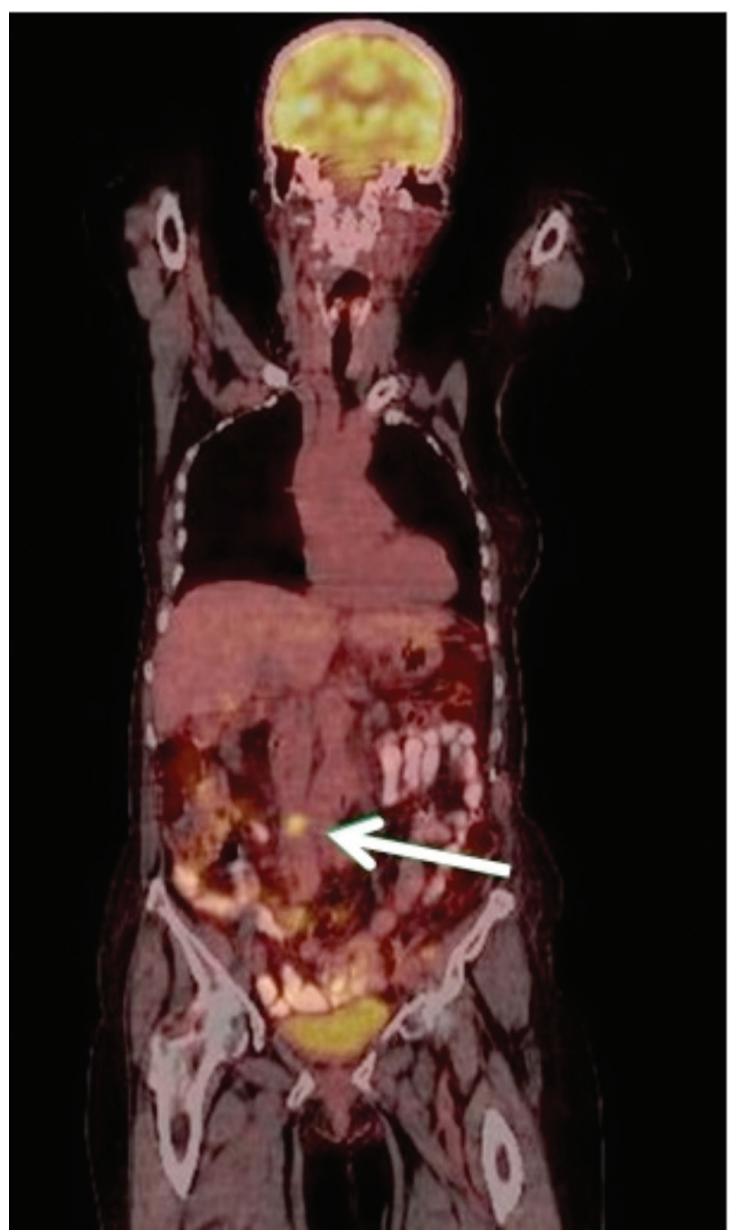

Figure 1. The coronal reconstruction of F-18 fluorodeoxyglucose positronemission tomography/computed tomography scans shows interaortocaval lymphadenopathy (arrow), maximum standardized uptake value: 7.2

scans is challenging due to of the physiological urinary activity of FDG. The physiological ${ }^{18} \mathrm{FDG}$ excretion of the renal collecting system should be differentiated from malignant pathological activity. The excretion of ${ }^{18} \mathrm{FDG}$ from pelvicalyceal system limits the sensitivity and specificity of the procedure in diagnosing urothelial cancers. The low expression of glucose transporters responsible for intracellular deposition of ${ }^{18} \mathrm{FDG}$ is one the most important reasons for reduced sensitivity in diagnosing primary urothelial carcinomas (10). However, re-staging of UTUC using ${ }^{18}$ FDG-PET/CT scans after radical nephroureterectomy overcomes the challenges pertaining to the urinary tract in monitoring response to treatment after chemotherapy and radiotherapy. Therefore, it allows the diagnosis of the lesions with higher accuracy and specificity. This method has some limitations only in diagnosing upper urinary tract tumors and metachronous bladder tumor. However, this did not appear as a limitation in the current study due to the fact that none of the patients had local recurrence in the bladder and other parts of upper urinary tract.

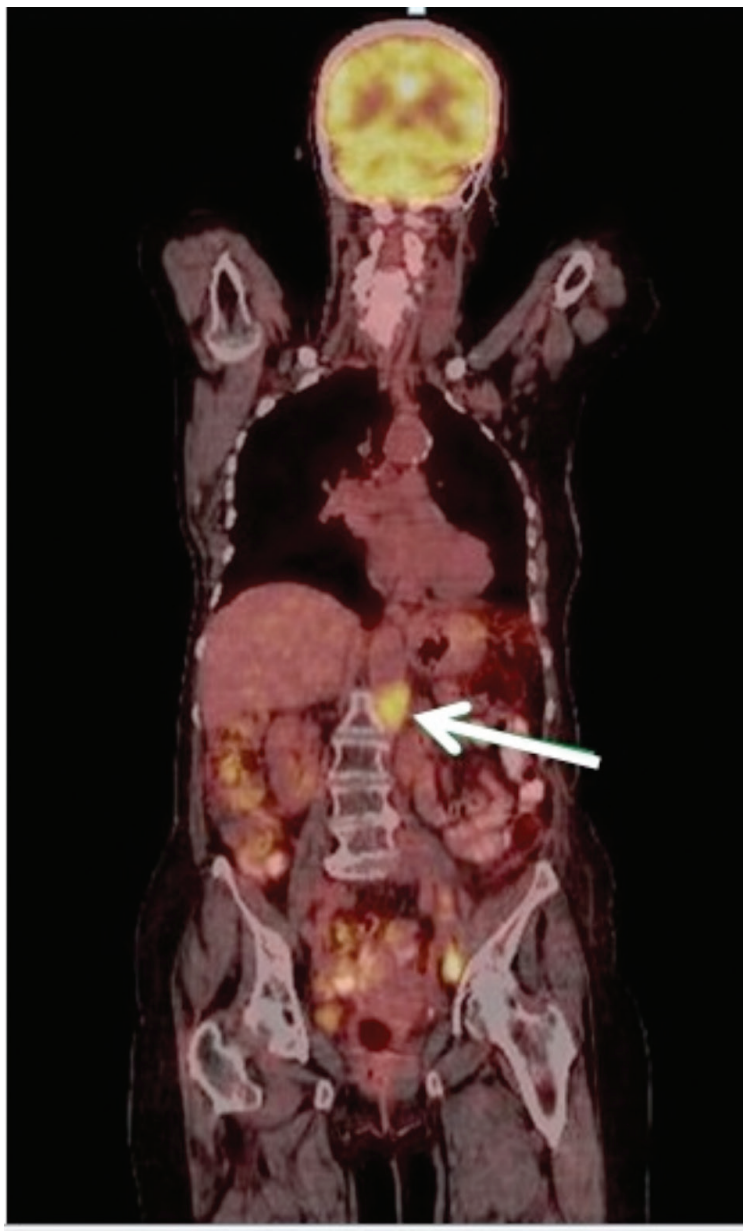

Figure 2. The coronal reconstruction of F-18 fluorodeoxyglucose positronemission tomography/computed tomography scans shows paraaortic lymphadenopathy (arrow), maximum standardized uptake value: 10.0

The most distinctive feature of the cancer tissue is that it shows higher glucose metabolism than normal tissues (Warburg effect) (11). High uptake of FDG in cancerous lesions of the transitional carcinoma was first demonstrated by Harney et al. (12) in rats. Drieskens et al. (13) found that metabolism-based anatomical information gathered by the addition of FDG-PET to CT provided high diagnostic accuracy in pre-operative staging of invasive transitional cancers particularly invasive bladder carcinoma. A study by Watanabe et al. (14) demonstrated hypermetabolism in TCC of the upper urinary tract and suggested that FDG-PET imaging might be also useful in detecting primary and metastatic lesions of TCC of the renal pelvis. Diuresis has been known to effectively decrease the background radioactivity in the urinary tract and hence facilitate the identification of hypermetabolic lesions on FDG-PET (15). 11C-methionine PET has been reported to be superior to F-18 FDG PET (16). 11C-choline was also tried due to its low level of urinary excretion. In the literature, studies conducted by Picchio et al. (17) and Gofrit et al. (18) found that PET or PET/CT scans using 11C-choline were superior to $\mathrm{CT}$ alone in diagnosing lymph node metastases in patients 


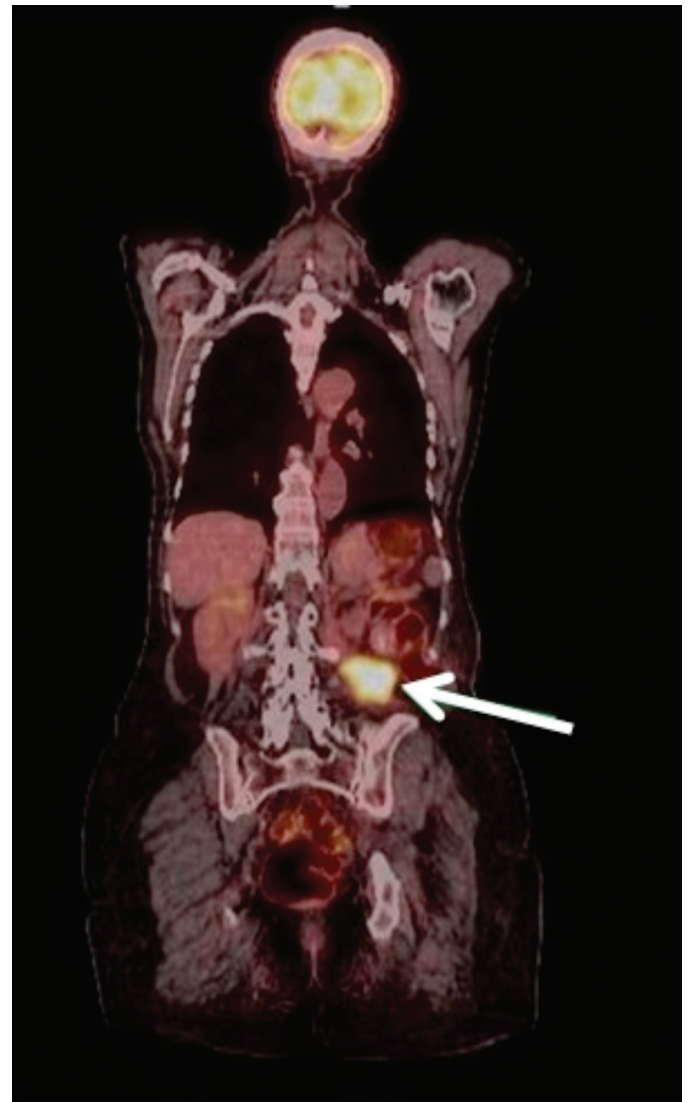

Figure 3. The coronal F-18 fluorodeoxyglucose positron-emission tomography/computed tomography scans show soft tissue metastasis in the left psoas muscle (arrow), maximum standardized uptake value: 11.3

with UTUC. UTUCs commonly spread to hilar, abdominal, paraaortic, paracaval regional lymph nodes (19). In particular, nephrectomy eliminates the problem of superimposition in visualizing metastasis to ipsilateral lymph nodes and provides high diagnostic accuracy.

In this regard, the sensitivity of ${ }^{18} \mathrm{FDG}-\mathrm{PET} / \mathrm{CT}$ scans in diagnosing regional lymph nodes can be further increased. Furthermore, FDG activity in the residual tissue after radiotherapy and chemotherapy may be useful in re-staging of the disease. MDCTU is used to detect lymph node or distant metastases however, it is known that metastasis can also come about in normal-sized lymph nodes. Therefore, false-negative results in MDCTU are a handicap for the use of this method in re-staging of UTUCs. Sun et al. (20) found positive correlation between the sensitivity of FDG and grade and stage of UTUCs. In their series of 27 patients with urothelial malignancies, Sun et al. (20) stated that PET could have a role in the prognosis of UTUC. In this study, the sensitivity and positive predictive value of FDG PET and CT were $67 \%$ vs. $59 \%$ and $90 \%$ vs. $84 \%$, respectively (20). In a series of 13 cases with metastatic UTUC reported by Dou et al. (21), PET/ CT was used in re-staging of the disease. In the study, a SUV of 3.8 was detected for the metastatic lymph nodes measuring
Figure 4. Maximum intensity projection images of a patient, interaortocaval lymphadenopathy (arrow)

$10 \mathrm{~mm}( \pm 2.2)$ in average. In these patients, the presence of metastatic disease was confirmed by pathological examination. After re-staging, the sensitivity and specificity were $87.5 \%$ and 92.3, respectively. Dou et al. (21) concluded that ${ }^{18} \mathrm{FDG}-\mathrm{PET} / \mathrm{CT}$ might play an important role in deciding on initial therapy and re-staging due to high sensitivity and specificity of this method in diagnosing local and/or distant metastases in patients with UTUC. Although average size of the lymph nodes was not available in the present study, 11 patients (64.7) were found to have lymph node metastasis. The mean SUV in these patients was 5.8 ( $\min : 3.6$, max: 11.3). The high sensitivity and specificity reported for ${ }^{18} \mathrm{FDG}-\mathrm{PET} / \mathrm{CT}$ in diagnosing patients with lymph node metastasis in the present study supports current literature data. The diagnostic performance reported for PET/CT scans in the literature is summarized in Table 2. We suggest that FDG-PET/CT is valuable in diagnosing lymph node metastasis considering the fact that this method detected lymph node metastasis with high accuracy in $64.7 \%$ of the patients in the present study. We assume that the fact that problems caused by physiologic renal excretion of FDG disappeared in all patients who underwent nephroureterectomy is particularly important in detecting lymph node metastasis. Therefore, PET/ CT is particularly recommended when lymph node metastasis 
Table 2. Diagnostic performance of positron-emission tomography and positron-emission tomography/computed tomography studies in the literature

\begin{tabular}{lllllll}
\hline Author & Modality & $\mathbf{n}$ & Sensitivity, \% & Specifity, \% & Accuracy, \% & PPV, \% \\
\hline Sun et al. (20) & PET/CT & 27 & $59(67)$ & - & - & $84(90)$ \\
Dou et al. (21) & PET/CT & 13 & 87.5 & 92.3 & - & - \\
Present study & PET/CT & 17 & 93 & 75 & 93.3 & 75 \\
\hline
\end{tabular}

PPV: Positive predictive value, NPV: Negative predictive value, PET/CT: Positron-emission tomography/computed tomography

is suspected due to its high sensitivity in detecting metastasis in normal-sized lymph nodes. Considering the fact that the mean SUV was 5.8 for lymph node metastasis and all patients had high-grade UTUC in the present study, ${ }^{18}$ FDG-PET/CT can provide useful information in patients with high-grade tumor and patients suspected to have lymph node metastasis. In the present study, four patients (23\%) had bone metastasis with a mean SUV of 8.8 (min: 5.4, max: 14.8). There have been studies reporting that $\mathrm{PET} / \mathrm{CT}$ offered high predictive value in detecting bone metastasis. Wu et al. (22) compared F-18 FDG PET and technetium-99m methylene diphosphonate bone scans and documented higher sensitivity and accuracy of PET in detecting bone metastases in patients with renal cell carcinoma. PET/CT is also superior to bone scintigraphy in demonstrating lytic bone metastasis. It has been suggested that ${ }^{18}$ FDG-PET/CT would be especially useful in patients with prostate cancer with lytic skeletal metastasis (23). ${ }^{18} \mathrm{FDG}-\mathrm{PET} / \mathrm{CT}$ can diagnose UTUC with bone metastasis with high sensitivity and specificity when considering the disadvantages of bone scintigraphy having high rates of false-positive results caused by degenerative bone lesions.

The metabolic rate of low grade TCCs is close to that of normal tissues. The increased glucose metabolism in patients with high grade UTUC allows visualization of the lesions on the detector due to increased FDG uptake. In the present study, 17 patients underwent ${ }^{18} \mathrm{FDG}-\mathrm{PET} / \mathrm{CT}$ for re-staging of the disease. Despite small sample size, ${ }^{18} \mathrm{FDG}-\mathrm{PET} / \mathrm{CT}$ showed negative findings in all patients with low-grade tumor. On the other hand, ${ }^{18}$ FDG-PET/CT showed positive findings in all patients with high-grade UTUC. Consistent with the literature data, there was a correlation between the tumor grade and positive PET/CT findings.

False-positive or false-negative results in FDG uptake cannot be related only to glucose metabolism of tumor tissue. The researches have showed that ${ }^{18} \mathrm{FDG}-\mathrm{PET} / \mathrm{CT}$ scans can render data solely in the existence of a number of and increased tumor cells with abnormal glucose metabolism $\left(10^{4}-10^{7}\right)$. Such diagnostic insufficiencies are particularly important in metastasis to solid organs such as the lungs and liver. In general, ${ }^{18} \mathrm{FDG}-\mathrm{PET} / \mathrm{CT}$ cannot precisely evaluate metastasis measuring less than $5 \mathrm{~mm}$ in size. After all studies, we still do not know why lung lesions below this threshold do not produce high SUVs. This can be caused by movement artifacts and low metabolic activity of the metastatic lesion. Decrease in movement artifacts using steady techniques, achieving a better spatial resolution and finding a higher cut-off SUV amounts for such lesions can extend diagnostic exactness (24).

The findings of PET/CT scans must be verified by histopathological work-up in order to confirm disease recurrence. Theoretically, PET/CT remains the standard imaging technique. However, in daily practice, this can be rarely possible because of clinical reasons, feasibility of the procedure and effective advantages of this approach in the absence of a radical surgical intention. In our study, histological verification was available in four patients and all the other ones were compared with clinical and radiological findings. In one patient with mediastinal lymphadenopathy with a SUV of 5.5, the existence of metastasis was confirmed by endobronchial ultrasound-guided biopsy. In another patient, solitary lung metastasis (SUV: 5.1) was confirmed by metastasectomy, and the patient was administered with cisplatin-based chemotherapy.

\section{Study Limitations}

The limitation of the study is its retrospective nature. A number of selection bias may have been demonstrated as it is probably that only those patients with UTUC suspected to have recurrence were referred for PET/CT.

\section{Conclusion}

${ }^{18} \mathrm{FDG}-\mathrm{PET} / \mathrm{CT}$ images supply complete structural-metabolic data and have the potential to significantly decrease the falsepositives of PET and CT performed individually. In spite of the limitations of our study due to its retrospective design and absence of systematic histological confirmation of pathological uptake, our outcomes are in compliance with the literature and suggest that ${ }^{18} \mathrm{FDG} \mathrm{PET} / \mathrm{CT}$ is characterised by high sensitivity and negative predictive value and could be useful in restaging UTUC. It is considered that the procedure could play a critical role in decisions regarding radiotherapy or chemotherapy and post-operative follow-up after the operation.

\section{Acknowledgments}

I would like to thank to İnanç Karapolat the head of department of nuclear medicine and director of cyclotron unit.

Ethics 
Ethics Committee Approval: All procedures followed were in accordance with the ethical standards of the responsible committee on human experimentation and with the Helsinki Declaration of 1975, as revised in 2000 . The study does not have approval of the ethical committee as it is retrospective.

Informed Consent: Informed consent was obtained from all patients for being included in the study. Additional information consent was obtained from all patients for which identifying information is included in this article.

Peer-review: Externally peer-reviewed.

Financial Disclosure: The author declared that this study received no financial support.

\section{References}

1. Roupret M, Zigeuner R, Palou J, Boehle A, Kaasinen E, Sylvester R, Babjuk $M$, Oosterlinck W. European guidelines for the diagnosis and management of upper urinary tract urothelial cell carcinomas: 2011 update. Eur Urol 2011;59:584-594.

2. Munoz JJ, Ellison LM. Upper tract urothelial neoplasms: incidence and survival during the last 2 decades. J Urol 2000;164:1523-1525.

3. Azemar MD, Comperat $E_{1}$ Richard $F_{1}$ Cussenot 0 , Roupret M. Bladder recurrence after surgery for upper urinary tract urothelial cell carcinoma: frequency, risk factors, and surveillance. Urol Oncol 2011;29:130-136.

4. Rouprêt $M$, Cancel-Tassin G, Comperat $E_{1}$ Fromont $G$, Sibony M, Molinié V, Allory $Y$, Triau $S$, Champigneulle J, Gaffory $C$, Larré $S$, de la Taille $A$, Richard F, Hamdy FC, Cussenot 0 . Phenol sulfotransferase SULT1A $1^{*} 2$ allele and enhanced risk of upper urinary tract urothelial cell carcinoma. Cancer Epidemiol Biomarkers Prev 2007;16:2500-2503.

5. Dillman JR, Caoili EM, Cohan RH, Ellis JH, Francis IR, Schipper MJ. Detection of upper tract urothelial neoplasms: sensitivity of axial, coronal reformatted, and curved-planar reformatted image-types utilizing 16-row multi-detector CT urography. Abdom Imaging 2008;33:707-716.

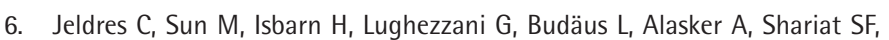
Lattouf JB, Widmer H, Pharand D, Arjane P, Graefen M, Montorsi F, Perrotte $\mathrm{P}$, Karakiewicz PI. A population-based assessment of perioperative mortality after nephroureterectomy for upper-tract urothelial carcinoma. Urology 2010;75:315-320.

7. Margulis $V$, Shariat SF, Matin SF, Kamat AM, Zigeuner R, Kikuchi E, Lotan Y, Weizer A, Raman JD, Wood CG; Upper Tract Urothelial Carcinoma Collaboration. Outcomes of radical nephroureterectomy: a series from the Upper Tract Urothelial Carcinoma Collaboration. Cancer 2009;115:12241233.

8. Hellenthal NJ, Shariat SF, Margulis V, Karakiewicz PI, Roscigno M, Bolenz C, Remzi M, Weizer A, Zigeuner R, Bensalah K, Ng CK, Raman JD, Kikuchi E, Montorsi F, Oya M, Wood CG, Fernandez M, Evans CP, Koppie TM. Adjuvant chemotherapy for high risk upper tract urothelial carcinoma: results from the Upper Tract Urothelial Carcinoma Collaboration. J Urol 2009;182:900906.

9. Hall MC, Womack JS, Roehrborn CG, Sagalowsky Al. Advanced transitional cell carcinoma of the upper urinary tract: patterns of failure, survival and impact of postoperative adjuvant radiotherapy. J Urol 1998;160:703-706.

10. Lin EC, Alavi A. Urologic Tumors. In: Lin EC, Alavi A. PET and PET/CT: A clinical guide. New York Thieme, 2009, pp. 204-211.

11. Gillies RJ, Robey I, Gatenby RA. Causes and consequences of increased glucose metabolism of cancers. J Nucl Med 2008;49(Suppl 2):24-42.

12. Harney JV, Wahl RL, Liebert $M$, Kuhl DE, Hutchins GD, Wedemeyer G, Grossman HB. Uptake of 2-deoxy, 2-(18F) fluoro-D- glucose in bladder cancer: animal localization and initial patient positron emission tomography. J Urol 1991;145:279-283.

13. Drieskens 0 , Oyen R, Van Poppel H, Vankan Y, Flamen P, Mortelmans L. FDGPET for preoperative staging of bladder cancer. Eur J Nucl Med Mol Imaging 2005;32:1412-1417.

14. Watanabe $N$, Kato $H$, Shimizu M, Noguchi $K$, Kamisaki $Y$, Fuse $H$, Matsunari I, Hisada K, Seto H. A case of renal pelvic tumor visualized by $18 \mathrm{~F}-$ FDG-PET imaging. Ann Nucl Med 2004;18:161-163.

15. López-Gandul S, Pérez-Moure G, Garcia-Garzón JR, Soler-Peter M, SimóPerdigó M, Lomeña F. Intravenous furosemide injection during 18F-FDG PET acquisition. J Nucl Med Technol 2006;34:228-231.

16. Jana S, Blaufox MD. Nuclear medicine studies of the prostate, testes, and bladder. Semin Nucl Med 2006;36:51-72.

17. Picchio M, Treiber U, Beer AJ, Metz $S$, Bössner $P$, van Randenborgh $H$, Paul $R$, Weirich G, Souvatzoglou M, Hartung R, Schwaiger M, Piert M. Value of 11C-choline PET and contrast-enhanced CT for staging of bladder cancer: correlation with histopathologic findings. J Nucl Med 2006;47:938-944.

18. Gofrit ON, Mishani E, Orevi M, Klein M, Freedman N, Pode D, Shapiro A, Katz R, Libson E, Chisin R. Contribution of 11C-choline positron-emission tomography/computerized tomography to preoperative staging of advanced transitional cell carcinoma. J Urol 2006;176:940-944.

19. Sobin L, Gospodarowicz M, Wittekind C. TNM Classification of Malignant Tumours. Urological Tumours. Renal Pelvis and Ureter. 7th revised edition, Wiley-Blackwell, uicc 2009:258-261.

20. Sun $\mathrm{SS}$, Chang $\mathrm{CH}$, Ding HJ, Kao $\mathrm{CH}$, Wu HC, Hsieh TC. Preliminary study of detecting urothelial malignancy with FDG PET in Taiwanese ESRD patients. Anticancer Res 2009;29:3459-3463.

21. Dou Y, Tretter C, Allison C, McKee B, Pinkus E. Value of 18F-FDG in the assessment of patients with upper tract urothelial carcinoma. J Nucl Med 2011;52(Supplement 1):1917.

22. Wu HC, Yen RF, Shen YY, Kao CH, Lin CC, Lee CC. Comparing whole body 18F-2-deoxyglucose positron emission tomography and technetium-99m methylene diphosphate bone scan to detect bone metastases in patients with renal cell carcinomas - a preliminary report. J Cancer Res Clin Oncol 2002;128:503-506.

23. Sharma $P$, Karunanithi $S$, Singh Dhull V, Jain S, Bal C, Kumar R. Prostate cancer with lytic bone metastases: 18F-fluorodeoxyglucose positron emission tomography-computed tomography for diagnosis and monitoring response to medical castration therapy. Indian J Nucl Med 2013;28:178179.

24. El Fakhri G, Surti S, Trott CM, Scheuermann J, Karp JS. Improvement in lesion detection with whole-body oncologic time-of-flight PET. J Nucl Med 2011;52:347-353. 